\title{
Institutionalizing cultural Europeanism: between transnationalism and national identity (1948-1954)
}

\author{
Luis Domínguez Castro ${ }^{1}$ and José Ramón Rodríguez $\mathrm{Lago}^{2}$ \\ Universidade de Vigo \\ e-mail: dominguez@uvigo.es; jrlago@uvigo.es \\ ${ }^{1}$ ORCID iD: https://orcid.org/0000-0003-0894-1641 \\ ${ }^{2}$ ORCID iD: https://orcid.org/0000-0003-4235-8863
}

Submitted: 24 May 2019. Accepted: 10 April 2020.

\begin{abstract}
Cultural Europeanism is a variant of the process of European integration attested within the framework of the Cold War. It will be mostly anti-communist, although it will couch elements favouring West-East dialogue. The governments will promote an intergovernmental model based on multilateral cooperation and national identity, and put into practice in institutions such as the Western Union or the Council of Europe. Non-governmental organizations, such as the European Movement, will be committed to a more transnational model based on the affirmation and promotion of the idea of Europe through institutions such as the College of Europe, the European Centre for Culture or the European Cultural Foundation. Within cultural Europeanism, networks of secondary institutionalization, such as educational seminars, ended up having as much or more impact than the primary entities from which they emerged.
\end{abstract}

KEYWORDS: Europeanism; Culture; Intergovernmentalism; Transnational; Anti-communism; European Movement.

Citation / Cómo citar este artículo: Domínguez Castro, Luis and Rodríguez Lago, José Ramón (2021) "Institutionalizing cultural Europeanism: between transnationalism and national identity (1948-1954)". Culture \& History Digital Journal, 10 (1): e009. https://doi.org/10.3989/chdj.2021.009

RESUMEN: Institucionalizando el europeísmo cultural: entre el transnacionalismo y la afirmación nacional (1948-1954).- El europeísmo cultural es una variante del proceso de integración europea que se vive en el marco de la Guerra Fría. Será mayoritariamente anticomunista, aunque habrá experiencias partidarias del diálogo Oeste-Este. Los gobiernos promoverán un modelo intergubernamental basado en la cooperación multilateral y la afirmación nacional, y desarrollado desde instituciones como la Unión Occidental o el Consejo de Europa. Las organizaciones no gubernamentales, como el Movimiento Europeo, apostarán por un modelo más transnacional basado en la afirmación y promoción de la idea de Europa a través de instituciones como el Colegio de Europa, el Centro Europeo de la Cultura o la Fundación Europea de la Cultura. Dentro del europeísmo cultural, las redes de institucionalización secundaria, como los seminarios del ámbito educativo, acabaron teniendo tanto o más impacto que las entidades primarias de las que emergieron.

PALABRAS CLAVE: Europeísmo; Cultura; Intergubernamentalismo; Transnacional; Anticomunismo; Movimiento Europeo.

Copyright: () 2021 CSIC. This is an open-access article distributed under the terms of the Creative Commons Attribution 4.0 International (CC BY 4.0) License. 


\section{INTRODUCTION}

At the beginning of 1958, Hendrik Brugmans, the then Rector of the College of Europe in Bruges, beseeched Salvador de Madariaga to accept being a part of the Council of Governors of the European Cultural Foundation because "il y a toujours des gens qui veulent faire de l'européanisme culturel comme si rien n'existait déjà". ${ }^{1}$ Brugmans' statement is revealing, not only about the efforts made by Europeanists in the cultural field, but also about the difficulty they had to face in order to fight their lack of visibility.

In the classic debate on transnational history promoted by the American Historical Review (henceforth AHR), Sven Beckert (2006, p. 1446) claimed that networks, institutions, ideas and processes serve as international links that go beyond political borders, which does not mean that the role played by governments, empires and states in the creation of those links should be underestimated. We will partially adopt a transnational perspective which does not intend to eclipse the role of nation-states or that of the actors who live between and through them (Saunier, 2013, p. 11). Nevertheless, we will give priority to the intergovernmental framework when dealing with the origin of the cultural Europeanism institutionalization process, as it establishes patterns and either favours or limits, as appropriate, the initiatives launched by non-governmental actors. We will mainly draw inspiration from the new fields of research in European integration history intended to supersede Lipgens' idealistic approach (1985, $1986,1988,1991)$, focused on federalist and resistance movements, as well as on their role during the first postwar years, and Milward's realistic approach $(1984,2000)$, focused on national interests and state-centred rational choice. The achievement of this goal would be possible thanks to research in new fields such as the formation of formalized and highly informal networks of actors whose intention is to have influence over European policymaking and over the slow emergence of a European-level polity. $^{2}$ The chronological context we have chosen enables us to learn more about a time when the United Kingdom was not only included in the integration process but also interested in taking the lead.

Halfway through the twentieth century, culture (or rather, moral and spiritual issues) enjoyed a privileged position in the international public agenda, as shown by the creation of United Nations Educational, Scientific and Cultural Organization (henceforth UNESCO), almost at the same time as that of the United Nations (henceforth UN). The national governments of the Europe of those days were not enthusiastic about the creation of a narrative of European cultural unity beyond borders and sovereignties. Furthermore, they had been promoting active cultural diplomacy to protect their own national interests for years, even for decades. For instance, France created its École Française d'Athènes (1846), its first Lycée in Istambul (1868), the École of Rome (1878) and, as a private initiative, the Alliance Française (1883); moreover, around 1900 the French Ministry of Foreign Affairs had an office in charge of all its educational institutions abroad. Prussia, for its part, had promoted 38 primary and secondary schools outside its borders before the unification of Germany and, in 1906, its Ministry of Foreign Affairs established a specific division aimed at promoting its educational institutions overseas. As for Italy, a group of outstanding people created the Società Dante Alighieri (1889) in order to foster an interest in the Italian language and culture, with the aid of public funding. For its part, the newly created Union of Soviet Socialist Republics (henceforth USSR) founded, in 1925, its own organization with the objective of promoting cultural exchange: the VOKS (Vsesoiuznoe Obshchestvo Kul'turnoi Sviazis zagranitsei). Finally, in 1934, after a period in which Great Britain considered that cultural diplomacy was just political propaganda, the country founded the British Committee for Relations with Other Countries, referred to as the British Council from the following year onwards (Haigh, 1974, pp. 29-36). ${ }^{3}$ The literary systems of each European country had settled enough to serve as a strong dyke against the desire of a certain homogenization around a common European culture (Hibbit, 2017) and played a key role against the institutionalization process of cultural Europeanism.

Nevertheless, during the first years of the postwar period, the need to fight the success of communism among intellectuals, as well as its attractive narrative of the new man, offered a window of opportunity for the birth of a unifying creed which would put together all the values of European cultural heritage against Asiatic bolshevism. Both British and North Americans welcomed this path, which found one of its core pillars in freedom, directly linked to human rights. ${ }^{4}$ Moreover, the horrors experienced during and after the war had resulted in a certain revival of religious beliefs, and Christian churches showed growing interest in debates on how to build the European society, including those related to the defence of human rights and to European unity (Chenaux, 1990; Leustean, 2014; Kratochvil and Doležal, 2015; Nelsen and Guth, 2015; Royce, 2017). These factors could favour cultural Europeanism, by opposing European solidarity to proletarian solidarity.

\section{What does culture mean to cultural Europeanists?}

The concept of culture, its scope and its actors go beyond the main purpose of these pages. However, it is necessary to know what we are talking about when we refer to cultural Europeanism. It did not play an insignificant role in the ideological battle which took place between the two blocs of the Cold War (Stonor Saunders, 1999; Scott-Smith and Krabbendam, 2004; Dongen, Roulin and Scott-Smith, 2014); consequently, we will make use of the definition of the term provided by the Council of Europe in its early years. On the $1^{\text {st }}$ of September 1949, a draft report was prepared in order to state that European culture was the secular work of free nations, a clear reminder that culture could not flourish in the soviet world. Culture is essentially diverse, as it is influenced by the structure and 
the living conditions of each nation, but it is also unique because it is based on respect for the human being, supremacy of spirit, freedom of thought and expression; in other words, it is opposed to all forms of oppression. It does not serve a particular nation or social class, it serves people. No power can prevent or hinder the free individual quest for truth. Every person has the right to culture to the same extent as to freedom; therefore, culture cannot be a privilege for the few. ${ }^{5}$ Likewise, in contrast with the soviet world, T. S. Eliot (1948) identified culture with an organic system of shared beliefs which cannot be produced artificially; rather, it is based on common heritage and transmitted from parent to child.

A few years later, at the beginning of 1952, the Council of Europe explained what the institution understood by "cultural". Taking the then popular book written by Ruth McMurry and Muna Lee (1947) as a starting point, the Council of Europe considered that any issues enabling to learn about each country's lifestyle (particularly about its teaching methods) were included in its scope of activity. As a result, there is a wide range of important actors in the field of cultural relations, thus understood. Especially important are teachers at all educational levels, university students, senior officials of the main public utility companies, Members of Parliament, writers, journalists and artists, intellectuals, engineers and architects, union and employers' associations leaders, jurists and military officers. ${ }^{6}$

\section{THE ORIGINS OF THE CULTURAL EUROPEAN- ISM INSTITUTIONALIZATION PROCESS}

The role of culture in society goes far beyond institutions; nonetheless, in the present work we will focus on the latter. When did the cultural Europeanism institutionalization process begin? There is no shortage of authors (Hässing, 2009, pp. 105-124) who state that the Rencontres Internationales de Genève (held for the first time in September 1946) represent the starting point of what such authors refer to as intellectual Europeanism (Geremek, 2007, p. 24; Barnavi and Pomian, 2008, p. 55). Indeed, this was a meeting place for discussion between supporters of Marxism (Julien Benda and Georg Lukásc) and opponents from other ideological backgrounds: existentialists (Karl Jaspers), non-conformist Christians (George Bernanos and Denis de Rougemont) and neo-converted (Stephen Spender). Nevertheless, we agree with Nicolas Stenger (2015, pp. 70-75) that such statement is not accurate, as it is not possible to separate the cultural Europeanism institutionalization process and the Cold War. In fact, there is some controversy around this if we consider that institutionalized cultural Europeanism is one of the factors which influenced the battle between the two blocs which were formed during the Cold War. Indeed, the Rencontres Internationales de Genève, organized by a group of Genevan writers, musicians and teachers, were intended to promote the dialogue between Marxist and non-Marxist intellectuals, by inviting personalities from both ideological backgrounds, including religious (also non-conform- ist) intellectuals. Some Marxist intellectuals were J.B.S. Haldane, Ernest Labrousse, Henri Lefebvre, Maurice Merleau-Ponty and Galvano della Volpe; non-Marxists include Robert Schuman, José Ortega y Gasset, François Mauriac, Mircea Eliade and Charles Morgan; among representatives of religious confessions stand out French cardinal Danielou, Swiss Protestant theologian Karl Barth, Hindu monk Swami Siddheswarananda, French Catholic intellectual Emmanuel Mounier, Anglican John Middleton-Murry and Swiss non-conformist Protestant theologian Roland de Pury. ${ }^{7}$

Therefore, it seems more appropriate to state that the origin of institutionalized cultural Europeanism dates back to the first months of 1948. Those were hectic days. In February, the Czechoslovak coup d'etat. In March, the foundation of the Western Union (henceforth WU). In April, the Organisation for Economic Cooperation and Development (henceforth OECD) at the beginning of the Marshall Plan. In May, the Congress of Europe and the Yugoslav-Soviet split. Finally, in June, the beginning of the Berlin Blockade. This is the context where cultural Europeanism started its institutionalization process; with hesitation, with tension between unionists and federalists concerning the construction of Europe.

During wartime, London offered asylum to many of the exiled European governments, as well as to a considerable number of intellectuals. The networks created at the time are the key to understanding the European unity projects which flourished in the late 1940s. The interests of the British played an important role in these projects, even though their goals were not always reached.

In February 1948, the British government founded the Information Research Department (IRD). Its inspirer, Ernest Bevin, stated that, in order to win the battle against communism, "We must put forward a rival ideology to communism" (Stonor Saunders, 1999, p. 49) based on democratic values and on Christian faith in Europe. This need for creating a set of European principles opposed to communist ideas was noticed by the British, who had a great influence on the other European elites and governments. In fact, both the labour government and the conservative opposition launched their own initiatives.

Indeed, Bevin himself promoted the creation of the WU, materialized through the Treaty of Brussels $\left(17^{\text {th }}\right.$ of March 1948). It should be noted that its official name is Treaty of Economic, Social and Cultural Collaboration and Collective Self-Defence and that it created a Cultural Commission (Guillén, 1997, pp. 326-327) which served as a model in cultural cooperation for the Council of Europe and the NATO, both founded a year later. ${ }^{8}$ London was the headquarters of the Cultural Commission; the British were the defenders of the intergovernmental cultural cooperation model.

As for Winston Churchill, in the opposition, he had left his son-in-law Duncan Sandys in charge of the United European Movement (henceforth UEM) as a tool for leading a unity process emanating from the civil society, in accordance with the British interests (Klos, 2016, pp. 
201-203). The supporters of both the Labour and the Conservative parties had something in common: they rejected the creation of a federal Europe. In this regard, the UEM had to use all its resources in order to avoid the potential supremacy of the Union of European Federalists (henceforth UEF).

There were two different spheres of action within the scope of cultural Europeanism: on the one hand, that controlled by national governments and parliaments; on the other hand, the transnational, led by different groups under the auspices of the European Movement and even by individual projects, with or without the support of the European Movement. Both spheres do not always move in different directions, as they often intertwine, especially with regard to their common need for financial aid from nongovernmental cultural organizations.
In institutionalization terms, the first sphere resulted in the foundation of the Cultural Committee of the WU and, almost immediately afterwards, in the creation of both the Commission and the Committee of Cultural Experts of the Council of Europe (Table 1), which enabled an important reciprocal transfer of policies and activities.

The second sphere gave rise to several initiatives which continued the legacy of the Rencontres Internationales de Genève, for instance, the European Society of Culture (henceforth ESC, Venice), and some others in the context of the Cultural Cold War, such as the Cultural Commission of the European Movement. The latter will sponsor of the European Academy, the College of Europe (Bruges) and the European Centre for Culture (henceforth ECC, Geneva), which, in turn, promoted the Association of Institutes of European Studies or the European Cultural Foundation, first in Geneva and then in Amsterdam (Table 1).

TABLE I. Cultural europeanism institutionalization process.

\begin{tabular}{|c|c|c|}
\hline \multicolumn{3}{|c|}{ Intergovernmental Organizations } \\
\hline Name & Founding members & Year \\
\hline $\begin{array}{l}\text { Cultural } \\
\text { Committee } \\
\text { (Western Union) }\end{array}$ & Great Britain, France, Luxembourg, Belgium and the Netherlands. & 1948 \\
\hline $\begin{array}{l}\text { Committee } \\
\text { on Cultural } \\
\text { and Scientific } \\
\text { Questions } \\
\text { (Council of } \\
\text { Europe) }\end{array}$ & $\begin{array}{l}\text { Belgium, Denmark, France, Ireland, Italy, Luxembourg, the Netherlands, Norway, Sweden } \\
\text { and Great Britain. }\end{array}$ & 1949 \\
\hline $\begin{array}{l}\text { Committee of } \\
\text { Cultural Experts } \\
\text { (Council of } \\
\text { Europe) }\end{array}$ & $\begin{array}{l}\text { Belgium, Denmark, France, Ireland, Italy, Luxembourg, the Netherlands, Norway, } \\
\text { Sweden, Great Britain, Greece, Turkey and Iceland. }\end{array}$ & 1950 \\
\hline \multicolumn{3}{|c|}{ Non-Governmental Organizations } \\
\hline Name & Promoters and/or members of the Executive & Year \\
\hline $\begin{array}{l}\text { Cultural } \\
\text { Commission } \\
\text { (European } \\
\text { Movement) }\end{array}$ & $\begin{array}{l}\text { Salvador de Madariaga (President), Étienne Gilson and Kenneth Lindsay (Vice } \\
\text { Presidents), Julien Cain and John Collins (Second Vice Presidents) Denis de Rougemont } \\
\text { (Rapporteur of the European Centre for Culture) and Jules Hoste (Rapporteur of the } \\
\text { College of Europe). Jean-Paul Dadelsen (Secretary). Bureau approved on 6-7 February } \\
1949 .\end{array}$ & 1948 \\
\hline $\begin{array}{l}\text { European Centre } \\
\text { for Culture }\end{array}$ & $\begin{array}{l}\text { Salvador de Madariaga (President), Raoul Dautry (Vice President), Denis de Rougemont } \\
\text { (Director), Raymond Silva (Secretary General), Hendrik Brugmans, Jean Drapier, } \\
\text { Joseph Retinger, Alessandro Casati and Eugen Kogon. All of them are members of the } \\
\text { Coordination Council. }\end{array}$ & 1950 \\
\hline College of Europe & $\begin{array}{l}\text { Salvador de Madariaga (President), Jean Drapier, Jules Hoste, Charles-Jean de la Vallée } \\
\text { Poussin, Karel Antoine Verleye, Jean Willens and L. De Winter. All of them are members } \\
\text { of the Executive Bureau of the Administrative Council. The first Rector was Hendrik } \\
\text { Brugmans and the first Director of Studies was Henri van Effenterre. }\end{array}$ & 1950 \\
\hline $\begin{array}{l}\text { European Society } \\
\text { of Culture }\end{array}$ & $\begin{array}{l}\text { Umberto Campagnolo, Antony Babel, Norberto Bobbio, Henri de Ziègler, Giorgio Falco, } \\
\text { Aldo Moro, Umberto Terracini, André Siegfried, André Gide, François Mauriac, Jean-Paul } \\
\text { Sartre, Étienne Gilson. These are some of the most renowned members of the Promotion } \\
\text { Committee. }\end{array}$ & 1950 \\
\hline
\end{tabular}




\begin{tabular}{|l|l|l|}
\hline $\begin{array}{l}\text { Association of } \\
\text { Institutes of } \\
\text { European Studies }\end{array}$ & $\begin{array}{l}\text { European University Centre (Nancy), Europa-Archiv (Frankfurt), Catholic Office of } \\
\text { Information and Initiative for Europe (Strasbourg), International Institute of Tours, } \\
\text { German Academy for Politics (Berlin), Austrian College Society (Alpbach) and College of } \\
\text { Europe (Bruges). }\end{array}$ & 1951 \\
\hline $\begin{array}{l}\text { European Cultural } \\
\text { Foundation }\end{array}$ & $\begin{array}{l}\text { Denis de Rougemont (Director), Robert Schuman, Hendrik Brugmans, Alberto Pirelli, } \\
\text { Marcel van Zeeland, Paul van Zeeland, Raymond Silva, George Villiers and Hermann } \\
\text { Reusch. All of them are members of the Council of Governors. }\end{array}$ & 1954 \\
\hline
\end{tabular}

Source: the authors.

\section{THE INTERGOVERNMENTAL WAY}

The cultural Europeanism institutionalization process at the intergovernmental level took place within the two pro-European organizations in which the British influence was greater during the first years of the European construction process: the WU and the Council of Europe. Their internal structure was not innovative, since they adopted well-known parliamentary and governmental models.

\section{The Cultural Committee of the Western Union (WU)}

This committee was comprised of important personalities in the Ministries of Education and in the services of cultural relations of the Ministries of Foreign Affairs from the five member states (The United Kingdom, France, Belgium, The Netherlands and Luxembourg). It began its activity almost at the same time as UNESCO, which compiled, to a considerable extent, the work carried out at the Conference of Allied Ministers of Education (henceforth CAME). The Committee was initially divided into five specialized subcommittees: Youth, Newsreels, Non-Commercial Cinema, Cultural Identity Card and Works of Art. ${ }^{9}$ Some time later, two more committees were added to this list: Education and Public Administration.

Despite the defensive nature of the WU, its Cultural Committee worked quite intensively, in its early years, in two specific fields: free movement of culture and education. In both cases, it went beyond what can be expected from a military organization, even though it did not achieve excellent results, a fact which has not been sufficiently highlighted in the literature (Milward, 1984, pp. 235-248; Coupland, 2004), with the exception of Raflik (2009, pp. 75-78).

Cultural freedom and mobility of intellectuals fitted in really well with the ideological battle between the two blocs, as it served as a mirror which reflected its absence in the soviet world, in addition to the fact that it had already been tried before 1945 (Charle, Schriewer and Wagner, 2004). The most innovative idea was the creation of a cultural identity card intended to facilitate travelling for non-commercial purposes among researchers, professors, senior staff of libraries, museums and archives, architects, musicians, painters and other renowned artists, as well as students. The privileges granted to the holders of this document were different depending on the country, but they included reduced transport fares and free or reduced tick- ets in museums, concerts, theatres and exhibitions, as well as assistance in obtaining or extending residence permits, foreign currency acquisition and accommodation. ${ }^{10}$ The card was valid from the $1^{\text {st }}$ of May 1950 and soon became the responsibility of the Council of Europe, which made it official for its 15 member states on the $1^{\text {st }}$ of June 1954.

The WU also showed interest in the development of the audiovisual sector, as a way of indoctrinating a population who was not used to reading and who anxiously went to the cinema every week to spend leisure time. This method had already been successfully used not only in Hitler's Germany but also in Stalin's USSR and New Deal America, just to mention three classic examples (Taylor, 2006; Schivelbusch, 2007; Welch, 2015). The most important initiative was the creation of a Central Association of Organised Newsreel Producers, which made it possible to bring together the main producers from all five countries, a recognized producer being defined as one who has for at least 104 successive weeks produced newsreels and screened them. ${ }^{11}$ The aim was to enable the private sector to manage newsreel exchange more easily, but this recommendation did not succeed and each producer (irrespective of whether it was private or public) continued to create its own versions in other languages in an attempt to use this as a cultural diplomacy strategy. The WU opted for the co-production of documentaries as well as for the national production of educational films about Physical Geography and History of Science. ${ }^{12}$ Radio and television productions did not materialize, either because of all the technical difficulties posed by the different existing definition systems, either as a result of the foundation, on the $12^{\text {th }}$ of February 1950, of the European Broadcasting Union, which assumed the role of coordinator. All efforts focused on the study of television as a teaching resource. In other words, the WU's pro-cultural freedom activism left its mark not so much in the form of tangible results but rather in the form of the creation of a space of flows which others (Council of Europe, Eurovision, Euroradio) continued. It served as an interesting intergovernmental cooperation lab.

The WU's cultural activism also focused on the educational field, at all stages (primary, secondary and university education). Methodology was based on the organization of seminars and work meetings in order to promote both debate and exchange of problem-solving techniques. School education was addressed in seminars with two different types of sessions: those aimed at teachers and those intended for school inspectors. That was the format of the three first editions, which took place 
in Ashridge (England) in 1949, Sèvres (France) in 1950 and Oosterbeek (the Netherlands) in 1951. Since then, the two kinds of seminars followed different paths: teachers kept organizing annual meetings, while inspectors started to gather every two years instead. Even though the work carried out by the WU in the cultural field was focused on the promotion of mutual understanding and cooperation among its members rather than on spreading the idea of Europe, it should be noted that the first three seminars for teachers were monographic: their main goal was to find the best way of transmitting basic concepts related to the European Western civilization. The most tangible result of these seminars was the publication of the brochure The Civilisation of Western Europe and the School, created by French educator Pierre Joulia and edited in English, French and Dutch. It contained a series of suggestions to help teachers address this issue in the classroom (Sidjanski, 1968, p. 125). The following seminars for teachers were more interested in access to the labour market; they dealt with issues such as education of young workers, agricultural education and farm schools, apprenticeships and vocational training. For their part, inspectors took advantage of their meetings to learn about other countries' teaching and inspection methods, as well as to visit emblematic institutions and to reflect on professional education, teachers' education and the use of audiovisual materials in the classroom. Exactly like what happened when talking about the above-mentioned cultural identity card, in this case the Council of Europe took up the torch and worked to give continuity to the institutionalization process of those ideas and processes which had been discussed in the meetings.

With regard to university education, UNESCO had already sponsored a conference in Utrecht in 1948 with the objective of analysing whether it was necessary to reform the university education system. ${ }^{13}$ In 1952 and 1953, The Hague hosted two seminars (organized by the WU) which were aimed at discussing university issues of common interest. In July 1955, the Council of Europe and the Western European Union (henceforth WEU), which had succeeded the WU on the $23^{\text {th }}$ of October 1954, jointly called an important conference to be held in Cambridge. This conference, chaired by the Duke of Edinburgh, dealt with the balance between specialization and general knowledge, the relationship between university and society, university's autonomy, and student education, wellness and selection processes. From an institutional point of view, the most important achievement was the creation of the European Universities Committee in Brussels as an advisory body to the Committee of Cultural Experts of the Council of Europe. ${ }^{14}$

\section{The cultural institutions of the Council of Europe}

As indicated above, many of the cultural activities carried out by the WU served as experiences almost immediately assumed by the Council of Europe. In fact, during the first session of its Consultative Assembly (August 1949), there was already a Committee on Cultural and
Scientific Questions; moreover, the Committee of Ministers resolved to create a Committee of Cultural Experts in 1950. In order to reinforce the idea of continuity in the work undertaken by the Cultural Commission of the WU, its members included senior officials from different Ministries of Education, as well as people in charge of cultural relationships in Ministries of Foreign Affairs. This Committee was very active during its first years of existence. In fact, it created the Subcommittee of the Five (subsequently called Committee Bureau) in order to organize meetings and discuss all kinds of issues. ${ }^{15}$ Such dynamism was also corroborated by the Belgian government, which stated that "Le Comité des Experts culturels est, en effet, le plus homogène et le plus actif de tous ceux qui collaborent à l'oeuvre de Strasbourg". ${ }^{16}$

Cultural cooperation was promoted in two different ways: by delving into the legal path followed by the multilateral agreements of the WU and by creating a cultural action programme specific to the Council. ${ }^{17}$ Multilateral agreements were formalized through conventions to which any interested countries could adhere, once approved. The first one, which dealt with recognition and comparison of qualifications to enter university, was signed on the $11^{\text {th }}$ of December 1953. The second one, the European Cultural Convention, was signed on the $14^{\text {th }}$ of December 1954 and was aimed at promoting mutual understanding in terms of language, history and culture thanks to proactive action on the part of the different international governments, which was a clear sign of their common desire to go beyond borders.

The above-mentioned cultural programme started in 1953 and was allocated French Francs (FF) 13,500,000, an amount which represented $1.49 \%$ of the total budget of the Council of Europe that year. In 1954, this figure increased to FF $16,500,000$, equivalent to $1.83 \%$ of the Council's annual budget, which was lower that year. ${ }^{18}$ As established by the patterns adopted by the WU in the context of cultural freedom, this programme offered university professors and intellectuals the opportunity to be granted scholarships for research stays in other European countries, as well as financial aid to cover the costs of professional training trips. As for the co-production of documentaries, this work was continued, to a certain extent, in the form of the so-called European exhibitions: Humanist Europe (opened to visitors for the first time in Brussels on the $15^{\text {th }}$ of December 1954) and The Triumph of Mannerism from Michelangelo to El Greco (inaugurated in Amsterdam on the $1^{\text {st }}$ of July 1955).

Educational activities were also an extension of the work previously carried out by the WU. In fact, a range of conferences and symposiums were organized in order to ensure a European dimension at school, capable of overcoming the atmosphere of mutual distrust which, rooted in nationalism, was still present in the classrooms. The Council's first priority was History textbook revision. Indeed, its work focused on trying to identify those topics which were not taught from a European perspective, but rather from a national point of view, in parallel with the work carried out by UNESCO and by the International Committee on In- 
tellectual Cooperation under the auspices of the League of Nations. Some symposiums were organized to discuss this issue, the first being held in Calw (Germany) in 1953. Next editions took place in Oslo (1954), Rome (1955), Royaumont (1956), Scheveningen (1957) and Ankara (1958). The Council of Europe stated that:

Son intention dans ce domaine n'est nullement d'utiliser l'histoire comme un moyen de propagande en faveur de l'idée européenne, mais seulement, en éliminant les erreurs et les présomptions traditionnelles, de veiller à ce que, dans l'avenir, les enfants étudient "l'histoire sans haine". ${ }^{19}$

Nevertheless, bringing the idea of Europe to schools was actually one of the aims of its cultural policies. In fact, it was thought that the development of a European civic spirit was closely related to teaching. In September 1952, there was a gathering of secondary education inspectors in Bruges to discuss this issue. The following year, Nancy hosted an event where experts reflected on how to introduce the idea of Europe both in primary education and in teacher training institutions. In July 1955, there was a similar debate in Sarrebruck, but this time at the university level. In order to reinforce this work, the Committee of Ministers asked Hendrik Brugmans and the College of Europe to create a handbook of European civic education whose draft was submitted in May 1953 but never got to be included in the school curricula.

\section{THE TRANSNATIONAL WAY}

From a transnational perspective, the cultural Europeanism institutionalization process took place in two parallel ways where boundaries between the public and the private spheres were blurred: one of them lay within the framework of the cultural Cold War (Lucas, 2002, 2003; Scott-Smith and H. Krabbendam, 2004; Laville and Wilford, 2006); the other one tried to keep the East-West dialogue alive.

The first of them was mainly supported by the European Movement and started at the Congress of Europe held in The Hague $\left(7^{\text {th }}-11^{\text {th }}\right.$ of May 1948). Culture was an area of disagreement between unionists and federalists (the latter were in charge of preparing the speech about culture). Duncan Sandys had planned a process which would be controlled from London, but Denis de Rougemont, the Rapporteur, was faster than him and sent a circular, in mid-February, to some 60 relevant personalities from the cultural field and also from the main Christian confessions, asking them to take part in the drafting of the speech. Afterwards, he called the first meeting of the Cultural Commission in Paris, on Sunday the $14^{\text {th }}$ of March. The event was attended by Rougemont, Kenneth Lindsay, Raymond Aron, Robert Aron, Alexandre Marc, Paul Gaultier, Stefan Glaser, Joseph Retinger and Lady Rhys Williams. ${ }^{20}$ According to Rougemont, the aim was to create a document showing the spiritual principles of European unity (freedom, democracy...) as well as to decide the terms of a declaration of individual and national rights and duties. As for Retinger, the future Secretary General of the European Movement, he stated that the work of the Cultural Commission would not be limited to The Hague Congress; quite the opposite, the institution would be in charge of promoting the idea of Europe after the Congress, especially within youth organizations.

Sandys counterattacked by creating, in mid-March, a cultural subcommittee in London, chaired by Kenneth Lindsay, a former minister of education (1937-1940). This subcommittee was in charge of delivering a paper to show the British point of view with regard to this matter. Rougemont was also invited to contribute. ${ }^{21}$ Even though Lindsay wrote up his own report and Madariaga prepared some notes as well, only Rougemont's report was presented at The Hague Congress, along with a motion for a resolution and also a specific report on human rights created by Marc. In order to ensure a certain geographical balance and, more particularly, to mitigate the low level of representation of the Italian delegation, Rougemont proposed that the Italian writer Ignazio Silone (one of the founders of the Italian Communist Party who had, nevertheless, become a renowned anti-communist) should chair the Cultural Committee at the Congress. However, an indisposition prevented him from attending the event, which resulted in his being replaced by Madariaga, who was Rougemont's second choice, in opposition to Sandys' preference for a representative of the Vatican (Deering, 1991, p. 261).

\section{The Cultural Commission of the European Move- ment}

After The Hague Congress, the setting up of the Cultural Commission of the European Movement slowly became a reality. On the $30^{\text {th }}$ of May 1948, the Executive proposed Madariaga to chair it. ${ }^{22}$ Shortly after, Madariaga drafted a note on the permanent bodies of the European Movement (including the Cultural Commission) and their relation with those institutions intended to promote $\mathrm{Eu}-$ ropean awareness. According to Madariaga, the Cultural Commission should be aimed at taking the leading role in the dissemination of the idea of European unity in the cultural field and should also encourage the setting up of those institutions whose creation had been approved in The Hague. Moreover, the Cultural Commission would serve as a delegate body of the Executive of the European Movement, to which it would submit its proposals. It would be formed by a small number of people expected to meet four times a year, and the headquarters would be either in London, Paris or Oxford. ${ }^{23}$ At the first gathering, which took place in September in Paris, it was agreed that the Commission would consist of seven members (Madariaga, Gilson, Lindsay, Rougemont, De Ruggiero, Hoste and Hurdes). The participants also proposed to organize a cultural conference in Lausanne in 1949 (which reminds of the strategy which was being employed to facilitate discussion on political and socioeconomic issues) and to keep working on the creation of a European Centre for Culture, an association of European universities and a European Academy, among others (Fig. 1). ${ }^{24}$ 


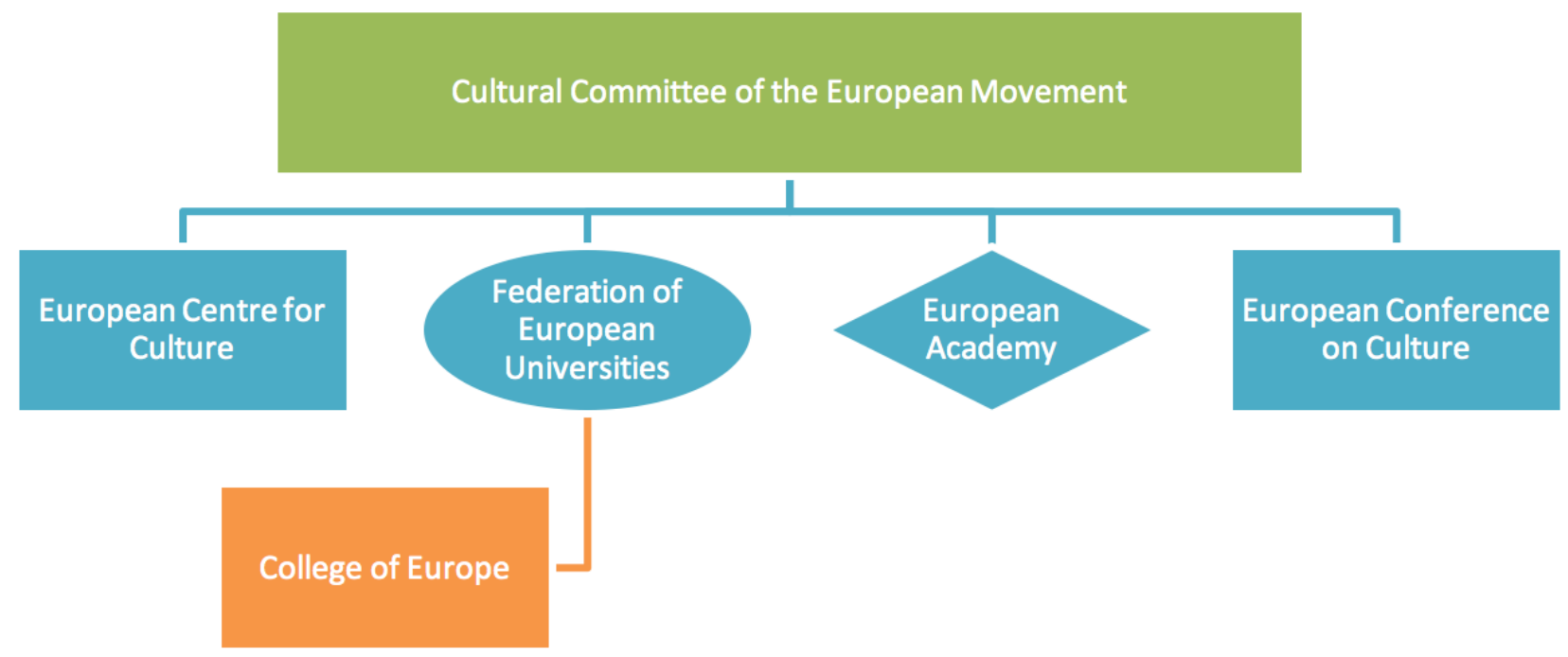

Source: the authors

At first, the members of the Commission gathered the day before the meetings of the Executive. This was convenient for Madariaga, an ex officio member of the institution, but revealed little interest in cultural issues, as these were always addressed in the latter part of the meetings, when everyone was eager to leave. ${ }^{25}$ The Commission itself had a quorum of only three or four members and, even so, this number was rarely exceeded. ${ }^{26}$ Madariaga, Lindsay and Rougemont were the most tenacious. Their absences were usually due to late notice or to the lack of resources to finance travel expenses. In absence of permanent headquarters, meetings were held in cities such as London, Paris, Brussels, Bruges and Geneva, where there were other events, in order to reduce costs. In 1949, its meetings became independent from those held by the Executive and, from August on, they started to be attended by delegates of the cultural sections of the National Councils of the European Movement. Nevertheless, there was a noticeable lack of material and human infrastructures, which resulted in Madariaga's constant stream of complaints. ${ }^{27}$ Proof of this is the statement of expenditure of the second semester of 1949, which shows that the total amount spent by the Commission was just $\nabla 939$-about $\bigotimes 155,000$ in current pounds-, a third of which was used to cover the salary costs of both Dadelsen (the secretary) and a typist, with the rest being used for travel expenses. ${ }^{28}$ Therefore, it was necessary to resort to the organizations and national Councils to which belonged the members of the Commission in order to finance their trips, as well as to ask Rougemont to allocate some of the funds raised in Switzerland to pay Dadelsen's salary and other expenses, due to the lack of resources as a result of non-payment of the fees on the part of many National Councils. ${ }^{29}$

Despite these constraints, and mainly in response to the World Congress of Intellectuals in Defence of Peace (held in Wroclaw in August 1948 under the aegis of com- munism), the European Conference on Culture took place in Lausanne from the 8th to the $12^{\text {th }}$ of December 1949, as scheduled. The Executive of the European Movement had resolved that Rougemont's Bureau d'études pour le Centre Européen de la Culture would be in charge of organizing the event, which was also supported by the European Movement and the Council of Europe. The conference was attended by the entire top brass of the Cultural Commission: Sandys (President of the Executive), Spaak (President of the Consultative Assembly of the Council of Europe) and Alessandro Casati (President of the Cultural Committee of the Assembly). Nonetheless, many authors who had been invited to attend the event were not present: T.S. Eliot, Alexis Léger, Alberto Moravia, Jules Romains, Carlo Levi, Gabriel Marcel, Louis de Broglie, André Siegfried, Arnold Toynbee, Albert Camus and Bertrand Russel. Obviously, communist sympathizers were not contacted. ${ }^{30}$ Among those who did attend the event, it should be noted that there were three British representatives (Richard Livingstone, President of Corpus Christi College; the renowned novelist Elizabeth Bowen and the poet Stephen Spender), one Italian (Silone) and one French (Raymond Aron). This poor level of attendance on the part of relevant people from the cultural field contrasted with that of the Congress for Cultural Freedom, only a few months later. This was probably due to organizational failures (Harris, 2016, pp. 39-74) and to insufficient funding, even though the American Committee on United Europe (henceforth ACUE) contributed United States Dollars (US\$) 1033.55. ${ }^{31}$

One of the institutions whose creation had been proposed at the first meeting of the Cultural Commission of the European Movement but came to nothing was the European Academy of Arts, Sciences and Humanities, Madariaga's most important failed initiative. He dreamt of an Academy which would play in the cultural field the 
same role that the Council of Europe played in politics. It would be the meeting point for creative spirits coming from different countries and disciplines, which would contribute to create a feeling of European patriotism. At first, the Executive of the European Movement accepted the proposal and agreed to organize a meeting in the summer of 1949 in Florence to discuss this. ${ }^{32}$ A list of proposed founding members (who would have the capacity to co-opt others) was submitted to the Executive for approval. ${ }^{33}$ Madariaga even contacted some of them, but as soon as February 1949 (when the Executive agreed to keep discussing the project) he began to understand that no progress was being made, so he informed Sandys that he was no longer taking the lead and that he would like Retinger (in his capacity as Secretary-General) to take charge of this task without delay. ${ }^{34}$ As for Rougemont, he did not show much enthusiasm either, for fear that the Academy might pose a threat to the ECC (Deering, 1991, p. 341), even though he did suggest some names and opposed others. ${ }^{35}$ The Academy, probably the most transnational of the institutions conceived during those years, never became a reality.

The Cultural Commission served to facilitate the cultural Europeanism institutionalization process, but had no decision-making powers, which were exclusively reserved to the Executive of the European Movement. It was also the framework of the confrontation between unionists, whose ideology was quite close to the postulates of national sovereignty (strongly defended by Lindsay and, to a lesser extent, by Gilson), in favour of the initiatives presented by the WU, and federalists (represented by Madariaga and Rougemont, among others), who preferred transnational principles and welcomed new proposals, such as the College of Bruges or the ECC. It should be noted that, after the first meeting of the Cultural Commission (September 1948), Lindsay prepared a memorandum $^{36}$ where, significantly, he analysed all the virtues of Article III of the Brussels Treaty, which dealt with cultural cooperation. As for Gilson, he opposed the creation of the ECC and agreed with Charles Morgan that it would be more useful to work in the same direction as the Brussels Treaty (Congress of Europe, 1999, pp. 337 and 348-450).

\section{The European Centre for Culture (ECC)}

Back then, several cities took part in a certain competition whose prize was to host the headquarters of the main European cultural institutions. Geneva, Lausanne, Bruges, Florence, Nancy or Tours are clear examples of this. The uncertainty which initially surrounded the ECC explains why Bruges was interested in being home to the institution in February 1949. ${ }^{37}$ This provoked a reaction on the part of Rougemont, who had just been authorized by the European Movement to establish the ECC in Geneva. ${ }^{38}$ However, the city of Bruges, the governor of West Flanders, the Belgian government and Madariaga bet high and the College of Europe soon became a post-graduate university institution specialized in European studies, prevailing over other initi- atives which tried to create a European university, without intruding on the domain of the existing national universities. ${ }^{39}$ It was not the ECC but the Executive of the European Movement that had to organize the preparatory session of the College (in October 1949), elect its first Rector (Hendrik Brugmans), supervise the programme and the lecturers for the first academic year and select the students with the aid of its National Councils.

From all the institutions created during those years, the most ambitious one was, undoubtedly, the ECC, which had its origins in a British idea taken from the report presented by Lindsay at The Hague Congress ${ }^{40}$ and succeeded thanks to the tenacity and the influence of its main supporter, Denis de Rougemont. The initial priority was to achieve financial self-sufficiency. The first offer came from Lausanne, which offered free facilities (no rent, no taxes) as well as Swiss Francs (CHF) 300,000 for setting up and first year $\operatorname{costs}^{41}$, but Rougemont managed to obtain a similar proposal from Geneva, opted for this one and raised some funds from private companies such as Nestlé (Stenger, 2015, p. 175). Nevertheless, a high-ranking executive of the European Movement, overwhelmed by the shortage of funds, decided that the money raised in Switzerland would be used to cover all types of expenses, not only those related to cultural issues. ${ }^{42}$ Rougemont showed his disagreement with what he considered an intrusion on the part of the British (mainly Sandys), who opposed the ECC because of the federalist ideas that Rougemont himself and his right hand, Raymond Silva (who had been the first Secretary General of the UEF), defended. ${ }^{43}$ Despite all these obstacles, Rougemont remained firm and continued to work. In fact, he edited an informative pamphlet on the ECC without prior consultation. Madariaga and Sandys, on behalf of the Executive, reacted to this by invalidating the publication and forcing Rougemont to rectify and cancel the distribution of the pamphlet. Rougemont justified himself by arguing that it was not possible to launch a campaign to increase the number of subscribers to the ECC without using an appropriate document to publicize the organization; besides, he highlighted that something similar had been done in Bruges without any recrimination. ${ }^{44}$ The rivalry with the College of Bruges also reached financial issues: Rougemont claimed that both institutions should be treated equally. Therefore, the ECC should not be compelled to give any money to the common fund, just like the College. ${ }^{45}$ The situation could only get worse when Spaak replaced Sandys at the head of the European Movement and decided to finance generously the European Youth Campaign, at the expense of the ECC. ${ }^{46}$ Attempts to get financial aid from the Council of Europe were not successful either, as the Consultative Assembly supported the proposal but the Committee of Cultural Experts and, as a result, the Committee of Ministers (in charge of subsidies), did not. As we have seen, the experts were senior officials with considerable experience in cultural diplomacy and no inclination to encourage competition without the supervision of national governments (Brunner, 2010), especially if such competition could affect well-established institutions, as 
pointed out by the French representative in a clear reference to UNESCO (Bossuat, 1997, p. 259).

Retinger intervened by persuading Marcel van Zeeland (manager of the Bank for International Settlements in Basel and former treasurer of the International Red Cross) to accept the post of treasurer of the ECC and to raise some money to help cover its expenses in 1951 (Stenger, 2015 , pp. 187-188). The following year, some financial aid came from Bonn's government. ${ }^{47}$ Despite being on excellent terms with Americans -Rougemont became the President of the Executive Committee of the Congress for Cultural Freedom, which included a salary (Stonor Saunders, 1999, pp. 142-167)-, neither the Rockefeller Foundation (which claimed that it did not finance organizations that received support from the government) nor the Ford Foundation (which alleged that the activity of the ECC lacked tangible results) contributed economically (Stenger, 2015, pp. 250-253). However, the ACUE (which worked undercover for both foundations when they wanted to secretly finance an initiative) donated US\$4002.15 between 1950 and April 1952. This amount far exceeded that received by the College of Europe from the ACUE in the same period (US\$1819.43). ${ }^{48}$

In an attempt to overcome financial constraints, Rougemont decided to create the European Cultural Foundation in 1954 to finance the activities of the ECC. At first, and thanks to the support given by Marcel van Zeeland and George de Villiers, at the head of the Council of European Industrial Federations, the situation seemed to improve. It was just an illusion. In 1960 under Prince Bernhard's presidency and with the support of Paul Rykens (the president of the British-Dutch company UNILEVER), both of whom were important founding members of the Bilderberg Group (Aubourg, 2003, 2010; Gijswijt, 2007), the Foundation moved to Amsterdam and stopped being attached to the ECC, which also lost Jean Drapier, the then President of the Executive Committee of the European Movement, because he did not approve Rougemont's financial management strategies. ${ }^{49}$

Nevertheless, Rougemont deployed all his leadership talents as a cultural agitator and was able to launch a wide range of interesting initiatives (Fig. 2). However, once materialized, these ended up getting out of hand, as happened with the Foundation. The Association of Institutes of European Studies can serve as an example: the first step consisted of identifying them and jointly organizing a periodic Conference in order to discuss Europeanist cultural cooperation issues. Their first proposal was the creation of a special passport (to be issued by the Council of Europe) which would enable its holders to enter any of the OECD countries as well as to acquire foreign currency more easily when travelling with cultural purposes, in line with what the WU was trying to implement. ${ }^{50}$ In 1951 , seven institutes signed the Bruges Protocol, which resulted in the creation of the Association. Uncertainty about dependence or not dependence on the ECC caused a delay of more than two years in the drafting of the association's bylaws, which did not prevent the Association from growing. In fact, there were 12 institutes from 5 different countries in $1954^{51}$ and these figures rose to 19 institutes from 7 countries in 1957 (Stenger, 2015, p. 203).

\section{The European Society for Culture (ESC)}

There was also an institution created outside the scope of the European Movement: the ESC. This was the only organization that did not follow the anti-communist pattern which characterized postwar cultural Europeanism in western countries. Furthermore, one of its most essential hallmarks was the defence of dialogue between the two Europes separated by the Cold War. Indeed, its journal was significantly titled Comprendre. However, this task was difficult to accomplish. Madariaga's correspondence serves as a good barometer. In August 1950, only three months after founding the institution, Umberto Campagnolo sent a copy of Comprendre to Madariaga (whom he had already met in person at the Reform Club, in London) and asked him to give his opinion on it. Madariaga's reply is very clear:

Vous professez vouloir faire le pont entre l'Est et l'Ouest, mais un pont doit être ouvert aux deux bouts, et, pour

FIGURE 2. Cultural institutions born of the European Centre for Culture (ECC)

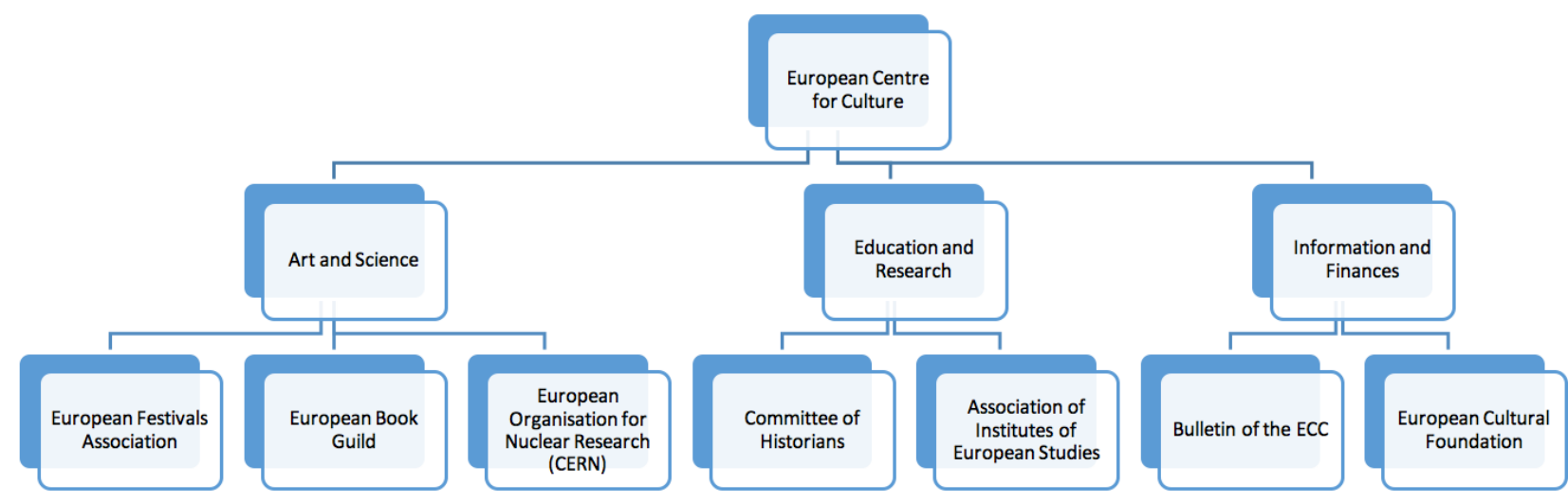

Source: the authors 
que votre revue fût vraiment ce qu'elle professe être, il faudrait qu'un exemplaire en russe parût à Moscou et y fût circulé librement. Je ne sais pas si vous êtes communiste. Si vous l'êtes, vous faites très bien votre métier. Si vous ne l'êtes pas, vous êtes un des promoteurs de ces "Clubs d'Innocents" fondés et contrôlés par Willi Münzenberg en vertu d'une décision du troisième Congrès du Komintern pour faire tomber les badauds dans le panier de Moscou. ${ }^{52}$

Some important personalities declined the offer from the first moment: Simone de Beauvoir, Einstein, Heidegger, Kelsen, Russell, Malraux, Ortega, Adorno and Lukács are good examples. However, it should be noted that the latter two ended up accepting years later (Jachec, 2015, p. 51). In contrast, there were also people who initially accepted and then quit. Karl Jaspers, Raymond Aron and Albert Camus, for instance, left the Society after the publication of Appeal to the Intellectuals of Europe and the World (approved by the institution in 1951), which defended the use of dialogue rather than the "you are either with me or against me" principle and the choice between the World Congress for Peace and the Congress for Cultural Freedom (Jachec, 2015, pp. 56-63). Louis Aragon, Marcel Prenant and Jean Frédéric Joliot-Curie, on the other side, were forced to resign by order of the French Communist Party, ${ }^{53}$ even though Joliot-Curie returned in 1953, as a result of the changes undertaken by the party. The Society, almost half of whose members were Italian, was a good example of transalpine politics. Umberto Campagnolo had been a resistance member connected to the National Liberation Committee, as well as the Secretary General of the European Federalist Movement (henceforth EFM) between October 1946 and mid-1947. He left the EFM when Spinelli decided to involve him in the Western European integration process. The headquarters of the ESC were located in Venice, partly due to the political and financial support of its communist mayor, Giovanni Battista Gianquinto, and partly due to the fact that such support was approved by Christian Democratic senator Giovanni Ponti, former mayor of the city and Commissioner of the Biennale between 1946 and 1954 (Jachec, 2015, pp. 38-39).

\section{CONCLUSIONS}

The vision of Europe as a homogeneous (but not uniform) cultural space dates far back in time, rather as a space of places than as a space of flows (Castells, 1999, pp. 457-462). The mid-decades of the twentieth century witnessed the progress of the European unity process in the framework of the devastation caused by the war. The hegemony shared by Soviets and Americans led Spaak to pronounce the following well-known words: "We Europeans live in fear of the Russians and on the charity of the Americans". Rougemont adapted them like this: "On the west side of the Iron Curtain, 325 million men live in fear of 190 million and on the charity of 155 million"
(Rougemont, 1959, p. 11). In other words, awareness-raising required the protection of nationalisms and the creation of a transnational European spirit. Institutionalized cultural Europeanism set that goal, supported by the governments and the civil society, even though such support was not equally enthusiastic in both cases and gradually became less intense. The Europeanism's institutionalization process did not succeed, for instance, in the European Communities or the Council of Europe and its Strasbourg Court. Achievements were much more modest. The world had been divided into two blocs, and cultural actors had to choose: either the World Congress for Peace or the Congress for Cultural Freedom. Third ways, both in cultural and political terms, were condemned to ostracism and incomprehension. Consequently, cultural Europeanism took the western bloc's side and defended anti-communism. Its institutionalization process was based on organizations such as the WU (later replaced by the WEU), the Council of Europe or the European Movement. Unorthodox experiences (for instance, the ESC) did not gain enough visibility. It can be stated that, when trying to create spaces of flows capable of influencing policymaking, secondary institutionalization networks such as educational seminars ended up proving more effective than the primary institutions which had given rise to them (for example, as regards the introduction of foreign languages in non-university curricula).

Those were hard times. Benefactors were scarce, and the States had more practical priorities to attend to. So did private entities, except for Switzerland or powerful America. It was not easy to get around Europe without dollars, as almost every other currency lacked credit. In a considerable number of countries (and not precisely of minor importance), hatred of others was much more powerful than interest in others. The task ahead was daunting, resources were scarce and individual actors seemed to be always the same. In fact, names such as Madariaga, Rougemont or Brugmans are to be found everywhere. The ECC seemed to be Rougemont's exclusive preserve; the College of Europe was Brugmans' territory. Madariaga, at the core of everything, could not fulfil his ambition: the creation of a European Academy. Egos and jealousy got in the way and ruined it all.

Transnational organizations play a crucial role; without them, progress is extremely slow. However, their autonomy, their dynamism and their efficacy are burdened with an endemic lack of resources. Indeed, only intergovernmental organizations are not affected by this constraint. Nevertheless, as explained in the present article, culture was allocated only $1 \%$ of the total budget, a figure that graphically demonstrates its position in their list of priorities, as well as the obstacles, in terms of visibility, which cultural Europeanism had to face.

\section{ACKNOWLEDGMENTS}

This work was carried out under MICINN research project PGC2018-095884-B-C21. Translated to English by Macarena Muradás Sanromán. 


\section{NOTES}

1 Instituto José Cornide de Estudios Coruñeses. Salvador de Madariaga Archive (IJC-FSM). Letter from Brugmans to Madariaga (27 January 1958), Box 171/2.

2 For more details about Lipgens and Milward, see Kaiser (2009, pp. 12-13). For more information on new research fields see Kaiser et al (2009, pp. 1-11).

3 More recent: Gienow-Hecht and Donfried (2010, pp. 33-136); Topić and Rodin (2012). For more information about the European spirit and cultural diplomacy, see Laos (2011, pp. 23-80 and 131-213).

4 The debate on the Universal Declaration of Human Rights organized by the UN was a clear example of this (Morsink, 1999, pp. 21-24; Lukina, 2017). For more information about the discussion on religious freedom in this forum, see Lindkvist (2017). For a more innovative vision of human rights as part of the conservative agenda, see Duranti (2017).

5 Commission des questions culturelles et scientifiques, projet de rapport à l'Assemblée (1 Septembre 1949) Available at: http:// coe.archivalware.co.uk/awweb/pdfopener?smd=1\&md=1\&did=720999 (accessed 5/May/2018)

6 Les activités culturelles du Conseil de l'Europe. Mémorandum présenté au Comité des Experts culturels par le Sous-Comité Consultatif des Cinq, Strasbourg, 24-28 avril 1952. Available at: https://rm.coe.int/16804e17e7\#search=\%22Comite\%20des\%20 experts\%20culturels\%22 (accessed 11/May/2018).

7 Rencontres Internationales de Genève. Liste des conférencier(ère)s. Avaliable at: http://classiques.uqac.ca/contemporains/ RIG/RIG_conferenciers.html (accessed 20/November/2018)

8 Notes from the Secretary General on the items on the agenda of the second session of the Committee of Ministers (Paris, 3rd November, 1949. Available at: http://coe.archivalware.co.uk/awweb/ pdfopener?smd=1\&md=1\&did=507150 (accessed 22/July/2017).

9 Rapport présenté à la Commission des Affaires Générales par le Secrétaire Général de la Commission Permanente du Traité de Bruxelles sur la coopération culturelle dans le cadre du Traité de Bruxelles. 15 mars 1950. Available at: http://coe.archivalware. co.uk/awweb/pdfopener?smd=1\&md=1\&did=715971 (accessed 26/May/2018)

10 Note du service d'information de l'Organisation du traité de Bruxelles (Union occidentale), du 14 mai 1950, sur la carte d'identité culturelle, appelée à faciliter les échanges culturels entre les cinq États membres de l'Union occidentale. Available at: https://www.cvce.eu/content/publication/2010/10/7/b30d46cb2117-44ea-a319-a3f16f7720ee/publishable_fr.pdf (accessed 31/ May/2018).

11 Secretary General's Report for the Committee on General Affairs of the Council of Europe. Co-operation in cultural matters in the framework of the Brussels treaty, 7. Available at: http:// coe. archivalware.co.uk/awweb/pdfopener?smd=1\&md=1\&did=715972 (accessed 21/November/2018).

12 Bilan des activités culturelles de l'UEO de 1948 à 1956 (Londres, septembre 1956), 15. Available at: https://www.cvce. eu/content/publication/2009/11/16/07c649f8-0b2d-4fed-8534 -ce9da95804c1/publishable_fr.pdf (accessed 26/May/2018).

13 IJC-FSM Letter from Julian Huxley to Madariaga (1 June 1948) Box 160/6.

14 In this Committee there were two university representatives and a senior official from each member state of the Western European Union (WEU), in addition to a university delegate from the rest of the countries which belonged to the Council of Europe. See Bilan des activités culturelles de l'UEO, 8.

15 At first, the committee was made up of Seymour (British; Secretary of the British Council), Reinink (Dutch; Secretary General of the Ministry of Education), Joxe (French; Director General of Cultural Relations of Quai d'Orsay), Mameli (Italian; Director General of Cultural Relations at the Ministry of Foreign Affairs) and Bodelsen (Danish; Professor of English). Rapport du Comité des experts culturels au Comité des Ministres, Strasbourg, le 1er mars 1951, Available at: http://coe.archivalware.co.uk/ awweb/pdfopener?smd=1\&md=1\&did=507603 (accessed 31/ May/2018)

16 Lettre du Secrétaire Général au Président du Comité des Experts Culturels, 30 novembre 1953. Available at : http://coe.archivalware.co.uk/awweb/pdfopener?smd=1\&md=1\&did=963250 (accessed 31/May/2018).

17 Cinq années d'activité du Comité des Experts Culturels. Rapport présenté au nom du Comité des Experts Culturels par M. Reinink à la Réunion Spéciale de la Commission des Questions Culturelles et Scientifiques (4-6 avril 1955) Available at: http:// coe.archivalware.co.uk/awweb/pdfopener?smd=1\&md=1\&$\mathrm{did}=731830$ (accessed 31/May/2018).

18 Projet de Budget pour l'exercice 1954 Doc. CM (53) 126. Available at: http://coe.archivalware.co.uk/awweb/pdfopener?sm$\mathrm{d}=1 \& \mathrm{md}=1 \& \mathrm{did}=596995$ (accessed 15/November/2018).

19 Cinq années d'activité du Comité des experts culturels, 8

20 HAEU Commission Culturelle. Réunion du Dimanche 14 Mars 1948: 45, Avenue d'Téna Folder ME-325.

21 The following people were invited to attend the event: the Dean of Westminster (Head), Professor Ifor Evans (Principal of Queen Mary College), Bertrand Russell (The 3rd Earl Russell), Sir Frederick Ogilvie (Principal of Jesus College, Oxford), Charles Morgan, Sir David Ross (Provost of Oriel College, Oxford), Dr R.E. Priestley (Vice Chancellor of the University of Birminghan), Professor Gilbert Murray, Lord Lindsay of Birker, Douglas Woodruff (editor of the Catholic periodical The Tablet), John Middleton Murry and Lionel Curtis. HAEU Cultural Sub-Committee. People invited to attend meeting at House of Commons on 19/III/48 Folder ME-325.

22 IJC-FSM Letter from Retinger to Madariaga, 15 June 1948. The approval letter sent in reply to Retinger's dates back to 17 June 1948. Box 158/4

23 IJC-FSM Note on the "Continuing Body" provided for in the Cultural Resolution of the Hague Congress. Box 158/4.

24 HAEU Decisions of the Cultural Study Group at meeting in Paris, 13th-15th September 1948. Folder ME-325. HAEU Meeting of the Executive Committee of the European Movement held in Paris on 11th and 12th September 1948, International Cultural Section of the European Movement, 1. Box ME-326.

25 IJC-FSM Letter from Madariaga to Sandys, 10 February 1949, Box 15/5. Madariaga resigned his position as President of the Cultural Commission. Sandys admitted that cultural issues had been postponed due to the existence of more urgent matters, noticeably the organization of the political (creation of the Council of Europe) and economic conference and committed himself to devoting more time to cultural issues in the near future: Letter written on 14 February 1949. Madariaga accepted his apologies and withdrew his resignation: Letter written on 18 February 1949. Box $15 / 5$

26 HAEU Decisions of the Cultural Study Group at meeting in Paris 13th-15th September 1948. Box 325.

27 IJC-FSM Letters from Madariaga to Sandys, 29 April 1949 and 1 December 1949; Letters from Madariaga to Retinger, 27 June and 21 July 1949; Letter from Madariaga to Curtis, 12 November 1949. Box $158 / 5$

28 HAEU Statement of expenditure incurred by the European Movement (London office) on behalf of the Cultural Section for 6 months to 8th December 1949. Box ME-326.

29 IJC-FSM Letter from Sandys to Madariaga, 12 January 1950. Box 158/6.

30 IJC-FSM Letter from Rougemont to Madariaga, 27 September 1949. Box $169 / 1$.

31 That year, the ACUE also financed the Westminster Economic Conference (US\$1142.82) and the founding meeting of the Consultative Assembly of the Council of Europe (US\$2777.78). Rockefeller Archive Center (Rockarch), Nelson A. Rockefeller Personal Projects. American Committee on United Europe, Contributions 1950. American Committee on United Europe. Statement of receipts and disbursements, February 16, 1949 to March 31, 1951, 1. Box 6, folder 59 .

32 HAEU International Cultural Section of the European Movement, 4. Box ME-326. 
33 From oldest to youngest: Croce (82), Murray (82), Gide (79), Claudel (79), Russell (76), Broglie (73), Jung (73), Schweitzer (73), Forster (69), Maritain (66), Sigrid Undset (66), Jaspers (65), Ortega (65), Duhamel (64), Bohr (63), Sibelius (63), Romains (63), Barth (62), Madariaga (62), Le Courbusier (61), Eliot (60), Toynbee (59) and Silone (48). IJC-FSM Note. Box 158/4.

34 IJC-FSM Letter from Madariaga to Sandys, 18 February 1949 , Box 158/5.

35 Dadelsen had suggested incorporating young writers such as Camus and Green, IJC-FSM Letter from Dadelsen to Madariaga, 28 October 1948. Box 158/4. With regard to this, Rougemont stated that 'l'un d'entre eux est l'auteur d'un seul livre, l'autre n'a jamais rien fait pour l'unité européenne", IJC-FSM Letter from Rougemont to Madariaga, 24 December 1948. Box 158/4.

36 See HAEU European Movement. Cultural Committee. Memorandum by Kenneth Lindsay M.P. Box 541.

37 HAEU Letter from Dunstan Curtis to Madariaga, 12 February 1949. Folder ME-311.

38 IJC-FSM Letter from Rougemont to Madariaga, 29 March 1949. Box 158/5.

39 IJC-FSM Letter from Madariaga to Julius Hoste, 12 September 1949. Box 170/1. IJC-FSM Mouvement Européen. Section Culturelle. Note sur le projet de Bruges. Box 170/1.

40 HAEU Joint International Committee of Movements for European Unity. Minutes of a meeting of the Cultural Sub-Committee held on Friday, 19th March 1948. Folder ME-432.

41 IJC-FSM Letter from Rougemont to Dadelsen, 18 October 1948. Box 158/4.

42 HAEU International Cultural Section of the European Movement, 7. Box ME-326.

43 IJC-FSM Letter from Rougemont to Madariaga, 24 December 1948, Box 158/4.

44 IJC-FSM Letter from Madariaga to Rougemont, 5 April 1949. Box 158/5.

45 IJC-FSM Letter from Rougemont and Silva to Madariaga, 16 November 1949. Box 158/5.

46 IJC-FSM Letter from Dadelsen to Madariaga, 6 November 1951. Box 169/3.

47 IJC-FSM Letter from Dadelsen to Madariaga, 16 May 1952. Box $158 / 8$

48 Rockefeller Archive Center (Rockarch) Durkee, William P., Report to the director of the ACUE, R. American Committee on United Europe 1952-1959, May 1952, 7-19. Box 58, folder 410.

49 IJC-FSM Letter from Drapier to Rougemont, 3 October 1957. Box 171/1. In his resignation letter, Drapier states that "Je constate que vous considérez qu'il est au pouvoir de la Direction $d u$ Centre de décider seule de la date d'expiration du budget et de celle de la reddition des comptes. Pour des raisons extrêmement simples tirées de la conception que je me fais d'une saine administration, il m'est tout à fait impossible d'approuver semblable manière de voir et je ne veux ni peux prendre aucune responsabilitê".

50 HAEU Note sur les Instituts Européens. Box ME-536.

51 IJC-FSM Tableau des principales activités du Centre Européen de la Culture. Box 169/6.

52 IJC-FSM Letter from Madariaga to Campagnolo, 17 August 1950. Box 174/32.

53 IJC-FSM Letter from Campagnolo to Madariaga, 28 August 1950. Box 174/32.

\section{REFERENCES}

Aubourg, V. (2003) "Organizing Atlanticism: The Bilderberg Group and the Atlantic Institute, 1952-1963". Intelligence and National Security, 18 (2), pp. 92-105. doi: https://doi.org/10.1080/026 84520412331306760

Aubourg, V. (2010) “The Bilderberg Group: Promoting European Governance inside an Atlantic Community of Values". In: W. Kaiser, B. Leucht and M. Gehler, ed., Transnational Networks in Regional Integration: Governing Europe 1945-83. Basingstoke: Palgrave Macmillan, pp. 38-60.

Barnavi, É. and Pomian, K. (2008) La Révolution européenne (1945-2007). Paris: Perrin.

Beckert, S. (2006) "AHR Conversation: On Transnational History". In "AHR Conversation: On Transnational History" participated by Ch. A. Bayly, S. Beckert, M. Connelly, I. Hofmeyr, W. Kozol and P. Seed. The American Historical Review, 111 (5), pp. 1441-1464.

Bossuat, G. (1997) "L'impossible Europe des socialistes au Conseil de l'Europe". In: M.-Th. Bitsch, ed., Jalons pour une histoire du Conseil de l'Europe. Berna: Peter Lang, pp. 249-276.

Brunner, J. (2010) "Le Conseil de l'Europe à la recherche d'une politique culturelle européenne, 1949-1968”. In: R. Frank, H. Kaelble, M.-F. Lévy and L. Passerini, eds., Building a European Public Sphere: From the 1950s to the Present. Bruxelles: Peter Lang, pp. 161-177.

Castells, M. (1999) La Era de la información. Economía, sociedad y cultura. Vol. II. El poder de la identidad. Madrid: Alianza Editorial.

Charle, Ch., Schriewer, J. and Wagner, P., eds. (2004) Transnational Intellectual Networks. Forms of Academic Knowledge and the Search for Cultural Identities. Frankfurt and New York: University of Chicago Press.

Chenaux, Ph. (1990) Une Europe Vaticane? Entre le Plan Marshall et les Traités de Rome. Bruxelles: Editions Ciaco.

Coupland, Ph. M. (2004) "Western Union, "Spiritual Union" and European Integration, 1948-1951", Journal of British Studies, 43, pp. 366-394. doi: https://doi.org/10.1086/383600

Deering, M. J. (1991) Combats acharnés: Denis de Rougemont et les fondements de l'unité européenne. Lausanne: Fondation Jean Monnet pour l'Europe.

Dongen, L., Roulin, St. and Scott-Smith, G. eds. (2014) Transnational Anticommunism and the Cold War: Agents, Activities, Networks. Basingstoke: Palgrave Macmillan.

Duranti, M. (2017) The Conservative Human Rights Revolution. Oxford: Oxford University Press.

Eliot, Th. S. (1948) Notes Toward a Definition of Culture. London: Faber and Faber. https://archive.org/details/in.ernet. dli.2015.159230/page/n3 (accessed 9/April/2019).

Geremek, B. (2007) "L'Europe en crise?". In: B. Geremek and R. Picht, eds., Visions d'Europe. Paris: Odile Jacob, pp. 9-28.

Gienow-Hecht, J.C.E. and Donfried, M. C. (2010) Searching for a Cultural Diplomacy. Explorations in Culture and International History. New York/Oxford: Berghahn Books.

Gijswijt, Th. W. (2007) Uniting the West: The Bilderberg Group, the Cold War, and European Integration 1952-1966. Heidelberg: Dissertation Universität Heidelberg.

Guillen, P. (1997) "Le Conseil de 1'Europe et la «construction culturelle» de 1'Europe, de sa création à la fin des années soixante". In: M.-Th. Bitsch, ed., Jalons pour une histoire du Conseil de l'Europe. Berna: Peter Lang, pp. 325-337.

Haigh, A. (1974) Cultural Diplomacy in Europe. Strasbourg: Council of Europe.

Harris, S. M. (2016) The CIA and the Congress for Cultural Freedom in the Early Cold War: The limits of making common cause. New York and London: Routledge.

Hässing, C. (2009) "Deux protagonistes genevois face à l'éclatement de l'Europe: les Rencontres internationales de Genève et le Centre européen de la culture". In: A. Fleury and L. Jilek, eds., Une Europe malgré tout 1945-1990. Contacts et réseaux culturels, intellectuels et scientifiques entre Européens dans la guerre froide. Bruxelles: Peter Lang, pp. 105-124.

Hibbitt, R., ed. (2017) Other Capitals of the Nineteenth Century: An Alternative Mapping of Literary and Cultural Space. Leeds: Palgrave Macmillan.

Jachec, N. (2015) Europe's Intellectuals and the Cold War. The European Society of Culture, Post-War Politics and International Relations. London-New York: I.B. Tauris.

Kaiser, W. (2009) "Transnational networks in European governance: 
the informal politics of integration". In: W. Kaiser, B. Leucht and M. Rasmussen, eds., The History of the European Union. Origins of a trans-and supranational polity 1950-72. London: Routledge/UACES contemporary European studies, no. 7, pp. 12-33.

Kaiser, W., Leucht, B. and Rasmussen, M. (2009) "Origins of a European polity. A new research agenda for European Union history". In: W. Kaiser, B. Leucht and M. Rasmussen, eds., The History of the European Union. Origins of a trans-and supranational polity 1950-72. London: Routledge/UACES contemporary European studies, no. 7, pp. 1-11.

Klos, F. (2016) Churchill's Last Stand: The Struggle to Unite Europe. London: I.B. Tauris.

Kratochvíl, P. and Doležal, T. (2011) The European Union and the Catholic Church. Political Theology of European Integration. Basingstoke: Palgrave Macmillan.

Laos, N. (2011) Foundations of Cultural Diplomacy: Politics Among Cultures and the Moral Autonomy of Man. New York: Algora Publishing.

Laville, H. and Wilford, H. eds. (2006) The US Government, Citizen Groups and the Cold War: The State-Private Network. London: Routledge.

Leustean, L. N. (2014) The Ecumenical Movement \& the Making of the European Community. Oxford: Oxford University Press.

Lindkvist, L. (2017) Religious Freedom and the Universal Declaration of Human Rights. Cambridge: Cambridge University Press.

Lipgens, W., ed., (1985, 1986, 1988 and 1991), Documents on the History of European Integration, vol. I «Continental Plans for European Union 1939-1945»; vol. II Plans for European union in Great Britain and in exile 1939-1945; and Loth, W., ed., vol. III The struggle for European union by political parties and pressure groups in Western European countries 1945-1950; and Loth, W., ed., vol. IV. Transnational Organizations of Political Parties and Pressure Groups in the Struggle for European Union, 1945-1950. Berlín and Nueva York: De Gruyter.

Lucas, W. S. (2002) "Mobilizing Culture: the State-Private Network and the CIA in the Early Cold War". In: D. Carter and R. Clifton, eds., War and Cold War in American Foreign Policy 19421962. Basingstoke: Palgrave Macmillan, pp. 83-107.

Lucas, W. S. (2003) "Total Culture and the State-Private Network: A Commentary". In: J. Gienow-Hecht and F. Schumacher, Culture and International History. New York: Berghahn, pp. 206-214.

Lukina, A. (2017) Soviet Union and the Universal Declaration of Human Rights. Max Planck Institute for European Legal History Research Paper Series, 01. Munchen: Max Planck Institute. https://papers.ssrn.com/sol3/papers.cfm?abstract_id=2952292 [accessed 12 April 2019]

McMurry, R. and Lee, M. (1947) The Cultural Approach. Another way in International Relations. Chapel Hill: University of North Carolina Press.

Milward, A. S. (1984) The reconstruction of Western Europe, 1945 51. Berkeley and Los Angeles: University of California Press.

Milward, A. S. (2000 [1992]) The European Rescue of the Nation State. London: Routledge.

Morsink, J. (1999) The Universal Declaration of Human Rights. Origins, Drafting \& Intent. Philadelphia: University of Pennsylvania Press.

Nelsen, B. F. and Guth, J. L. (2015) Religion and the Struggle for European Union: Confessional Culture and the Limits of Integration. Washington D.C: George Town University Press.

Raflik, J. (2009) "Le traité de Bruxelles, prelude à la construction atlantique ou veritable étape de la construction européenne?". In : Guieu, J.-M. and Le Dréau, Ch., ed., Le "Congrès de l'Europe" à La Haye (1948-2008). Bruxelles: Peter Lang, pp. 67-78.

Rougemont, D. de (1959) “Tomando conciencia de Europa". In: La mesa redonda de Europa. Zaragoza: Sagitario.

Royce, M. R. (2017) The Political Theology of European Integration: Comparing the Influence of Religious Histories on European Policies. Springfield: Palgrave Macmillan.

Saunier, P.-Y. (2013) Transnational History. Basingstoke: Palgrave Macmillan.

Schivelbusch, W. (2007) Three New Deals: Reflections on Roosevelt's America, Mussolini's Italy, and Hitler's Germany, 19331939. New York: Metropolitan Books.

Scott-Smith, G. and Krabbendam, H., eds. (2004) The Cultural Cold War in Western Europe, 1945-1960 (Studies in Intelligence). London: Routledge.

Sidjanski, D. (1968) "Rapport sur la Communauté Universitaire Européenne". In: C. J. Friedrich, ed., Politische dimensionen der Europäische Gemeinschaftsbildung. Köln und Opladen: VS Verlag für Sozialwissenschaften, pp. 105-224.

Stenger, N. (2015) Denis de Rougemont. Les intellectuels et l'Europe au XX siècle. Rennes: Presses Universitaires de Rennes.

Stonor Saunders, F. (1999) Who Paid the Piper? The CIA and the Cultural Cold War. London: Granta Books.

Taylor, R. (2006) Film Propaganda: Soviet Russia and Nazi Germa$n y$. London: I.B. Tauris.

Topić, M. and Rodin, S. (2012) Cultural Diplomacy and Cultural Imperialism: European Perspective(s). Brussels: Peter Lang.

Welch, D., ed. (2015) Nazi Propaganda: The Power and the Limitations. London: Routledge. 